\title{
Grænser for religion
}

\author{
PETER LÜCHAU
}

ENGLISH ABSTRACT: Where and in what context Danes accept religion is dependent upon their attitudes toward the boundaries of religion. Dependent upon the theoretical point of departure, the boundary may be expected to be situated between religion in the public and the private sphere (secularization theory) or between religious exercise of authority and religious self-expression (individualization theory). To determine which theory may best explain the Danes' view concerning the acceptable place of religion in Denmark, data from the International Social Survey Programme 2008 - Religion III questionnaire are utilised. The analysis shows that the boundary of religion is situated at the point of religious exercise of authority, and thus individualization theory best explains the limits of religion in Denmark. Furthermore, it can be shown that this boundary is part of the existing value-based cleavages among the Danes.

DANSK RESUMÉ: Hvor og $i$ hvilken sammenhæng danskerne accepterer religion, afgøres bl.a. af deres holdning til, hvor grænsen går for religion $i$ samfundet. Alt efter teoretisk udgangspunkt forventes grænsen at gå mellem religion $i$ det offentlige og det private rum (sekulariseringsteori) eller mellem religiøs autoritetsudøvelse og religiøs selvudfoldelse (individualiseringsteori). Til at afgøre hvilket teoretisk udgangspunkt som bedst forklarer danskernes syn på religions rette plads i Danmark, benyttes data fra International Social Survey Programme 2008 - Religion III sporgeskemaundersøgelsen. Det viser sig, at grænsen for hvor danskerne vil acceptere religion går ved religiøs autoritetsudøvelse, og dermed at individualiseringsteori bedst forklarer grænsen for religion i Danmark. Det kan ydermere vises, at denne grænse er en del af de eksisterende værdimæssige kløfter blandt danskerne.

KEYWORDS: Limits of religion; quantitative analysis; International Social Survey Programme 2008; secularization; individualization; values 
Ligesom den danske religionsmodel har politiske og juridiske grænser, kan man påstå, at den også har holdningsmæssige grænser. Al religion i Danmark har et råderum. Der er steder, hvor danskerne generelt mener at religion er velkommen, og der er steder, hvor de mener at den ikke er velkommen. Der er ting, religion må, og ting den ikke må. Man kan sige, at danskerne har en holdning til religion og navnlig til religions rette plads, som sætter grænser for religion, ligesom jura og politik gør det. Det er dog vigtigt at forstå, at de juridiske, politiske og holdningsmæssige grænser for den danske religionsmodel ikke altid er sammenfaldende. At bygge en moske er fuldt ud i tråd med grundlovens $\S 67$, som jo netop fokuserer på samling med det formål at dyrke en gud, men såvel den politiske som den folkelige modstand kan være særdeles stor. Når de politiske, juridiske og holdningsmæssige grænser for den danske religionsmodel altså ikke kan antages at være sammenfaldende, må de nødvendigvis studeres hver for sig. De holdningsmæssige grænser for den danske religionsmodel vil blive beskrevet og søgt analyseret i denne artikel. Dels fordi de er underbelyste, dels fordi det vil kunne supplere eksisterende studier af de juridiske og politiske grænser. Målet er derfor: 1) at vise hvor de holdningsmæssige grænser for den danske religionsmodel går, altså hvor danskerne generelt mener, at religion har sin plads, og navnlig hvor den ikke har, 2) at forklare hvorfor grænserne går, hvor de går og 3) at undersøge om de holdningsmæssige grænser for den danske religionsmodel følger eksisterende værdimæssige kløfter blandt danskerne. Til at undersøge danskernes holdninger til religions rette plads i samfundet, bruger jeg data fra International Social Survey Programme 2008 - Religion III spørgeskemaundersøgelsen.

\section{Grænser for religion i Danmark}

Man kan påstå, at Danmark har en religionsmodel; der er et sæt former og rammer, inden for hvilke religion institutionelt, sociologisk og historisk udfolder sig i Danmark (se Christoffersen et al. 2012, 14). Der er mange faktorer, som er og har været med til at definere de former og rammer, som religion fungerer under i Danmark, men der er tre, som er særlige derved, at de er aktive og intentionelle forsøg på at sætte grænser for religion (også selv om deres konsekvenser ikke nødvendigvis var den oprindelige intention). Disse tre er, hvad man kan kalde de politiske, juridiske og holdningsmæssige grænser for den danske religionsmodel. De politiske grænser for religion i Danmark skabes og defineres af politikerne gennem deres offentlige udtalelser og via de love, de vedtager. Man forsøger fra politisk side at afstikke nogle grænser for, hvad man vil acceptere af religion og religiøse former i Danmark. Politikere på højrefløjen af dansk politik kan f.eks. mene, at folkekirken skal have en særposition i kraft af dens lovfæstelse i grundloven, men samtidig fastholde, at denne særposition ikke må stå i vejen for dansk flygtningepolitik, som det for eksempel er sket, når præster har tilbudt asyl til udviste i kirkerummet. Juraen sætter grænser for religion gennem juristers og dommeres tolkning af de love, som har med religion at 
gøre; tolkninger som ikke nødvendigvis flugter de intentioner, som politikerne havde, da de vedtog lovgivningen. En af grundene til det er, at Danmark i dag er et meget anderledes sted end i 1849, da grundloven og hermed religionsparagrafferne blev vedtaget. De holdningsmæssige grænser for religion i Danmark skabes af befolkningen gennem deres eventuelle accept af religiøs fremfærd. Folk reagerer på religion på en måde, som antyder et bagvedliggende mønster. Det kan være anekdoter om, hvordan man har smækket døren i hovedet på Jehovas Vidner eller udtalelser om, hvor glad man er for (folke)kirkerne i byrummet. Det kan også som her være svar på spørgsmål stillet i en samfundsvidenskabelig spørgeskemaundersøgelse.

Fordi der vil altid være uenighed i en befolkning om, hvor religion har sin rette plads, og hvor den er uønsket, vil der ikke være ét punkt, hvor religion går fra at være accepteret til uønsket. Men der vil alt andet lige være områder, hvor religions tilstedeværelse vil være mindre kontroversiel end i andre områder. Den holdningsmæssige grænse for religion i Danmark kan postuleres at ligge et sted mellem det, som et flertal af danskerne finder acceptabelt, og det som et flertal finder uacceptabelt. Grænsen er således flydende og til forhandling. Grænsen er en abstraktion, men den siger ikke desto mindre noget vigtigt om, hvor danskerne ser religions rette plads i det danske samfund.

Som sagt er der ikke fuldstændigt sammenfald mellem de tre typer af grænser for den danske religionsmodel. Man kan argumentere for, at grænserne i høj grad skabes i et med- og modspil mellem de tre former for grænser. Politikerne laver love, som de mener udtrykker de holdningsmæssige grænser, som danskerne definerer. Jurister tolker dernæst lovene og gør dem til en del af den konkrete virkelighed, som danskerne lever i. Den virkelighed kan så påvirke danskernes holdninger til religions plads og dermed rykke på de holdningsmæssige grænser for den danske religionsmodel. Med- og modspillet mellem de tre typer af grænser kompliceres også af, at de eksisterer og opretholdes på forskellige analytiske niveauer. Man kan argumentere for, at de politiske og juridiske grænser for den danske religionsmodel primært skabes og virker på samfundsniveau, mens holdningsmæssige grænser skabes kollektivt og primært virker på individniveau.

At beskrive de værdimæssige grænser for den danske religionsmodel kan give et fundament til at forstå det med- og modspil, som er mellem de tre typer af intentionelt skabte grænser for religion i Danmark, og dermed bidrage til en bedre forståelse af den danske religionsmodel, som den udvikler sig i disse år. Studier af de politiske og de juridiske grænser findes allerede (Jacobsen 2012; Christoffersen 2012), mens der mangler klarhed over de holdningsmæssige grænser. At beskrive hvor danskerne mener, grænserne for religion går, hvor givtigt det end måtte være, er dog ikke nok. Sociologisk set er det eventuelt bagvedliggende princip mindst lige så vigtigt. Når den holdningsmæssige grænse i den danske religionsmodel jo netop handler om religion, må den kunne forklares af teorier, som allerede kan forklare religion i Danmark i dag. Er det tilfældet, kan de holdningsmæssige grænser ikke blot forklares 
sociologisk, men det kan også antyde, hvordan grænserne vil ændre sig i fremtiden. Forandres eksisterende religioner i Danmark eller kommer der nye til, vil de skulle indpasses i den danske religionsmodel. Hvis man sociologisk kan forklare principperne bag grænserne for religionsmodellen, vil det (med en hvis sandsynlighed) kunne forudses, om disse nye former for religion vil blive accepteret af danskerne generelt. Blandt danskerne bør der være en vis konsensus om, hvor de mener, at grænserne for den danske religionsmodel bør gå, og jo mere en religion afviger fra denne konsensus, jo mere afvisende vil danskerne som helhed være over for den. Kan danskernes holdning til religions rette plads i samfundet ikke forklares af de teorier, som kan forklare religion i Danmark i dag, er det i sig selv bemærkelsesværdigt. Det antyder, at religion og synet på religion er blevet to adskilte størrelser. For at der kan eksistere en holdningsmæssig grænse, må der være enighed om den. Danskerne har ikke samme religiøsitet endsige samme holdning til religion (Andersen \& Lüchau 2011), hvilket antyder, at de heller ikke vil være enige om de holdningsmæssige grænser for den danske religionsmodel. Spørgsmålet er så, om denne uenighed vil flugte eksisterende politiske og holdningsmæssige grænser og dermed være en del af de eksisterende værdimæssige kløfter blandt danskerne, eller om religion er et særskilt emne, som deler danskerne på en særlig måde.

\section{Sekularisering}

Skal man forsøge at forklare de holdningsmæssige grænser for den danske religionsmodel ud fra eksisterende teorier om religion i Danmark i dag, skal disse teorier være relevante for religion på individniveau. Årsagen til dette er, at de holdningsmæssige grænser skabes kollektivt og virker på individniveau. Alt efter emnet er den teori, som bedst kan forklare religion på individniveau i Danmark i dag enten sekulariseringsteori (se Lüchau \& Andersen 2012) eller individualiseringsteori (Andersen \& Lüchau 2011).

Sekulariseringsteori har ikke umiddelbart nogen forventninger til befolkningens holdninger til religions rette plads i samfundet. Teorien er konstrueret til at forklare religions vilkår i en moderne verden, og de konsekvenser moderniseringen har. Den måde, hvorpå sekulariseringsteori forklarer den religiøse udvikling, giver dog et fingerpeg om, hvordan man må forvente, at befolkningen forholder sig til religions rette plads.

Et fingerpeg kan findes i den belgiske sociolog Karel Dobbelaeres idé om et mellemstadium, som skal kunne forklare, hvordan sekularisering på samfundsniveau påvirker sekularisering på individniveau. Påstanden er, at når religion på samfundsniveau mister sin evne til at integrere og legitimere samfundet som helhed, vil individer i stigende grad få den overbevisning, at religion simpelthen ikke hører til andre steder end i det religiøse subsystem. Ligesom religion er blevet skilt fra økonomi, politik og videnskab på samfundsniveau, vil det også ske i folks bevidsthed. Dob- 
belaeres pointe er, at det er denne sekularisering-i-sindet, som fører til religiøs nedgang på individniveau (Dobbelaere 2002, 169), men det interessante i indeværende sammenhæng er, at dette mellemstadium antyder, at individer betragter religions rette plads som værende i det specifikt religiøse. Når man skal giftes, må det godt ske i en kirke, men når parret skal låne penge til det nye rækkehus, har hverken præst eller kirke nogen rolle at spille. Det betyder omvendt, at individer burde anse religion for upassende i det offentlige rum, som jo netop ikke længere er religiøst.

Et andet fingerpeg kan findes i den tyske sociolog Thomas Luckmanns påstand om, at sekularisering fører til privatisering af religion (Luckmann 1967). Luckmann ser religion som en social størrelse, men hvor den sociale gruppe, som opretholder en religion, før var hele samfundet, er den nu reduceret til kernefamilien. Kun inden for kernefamiliens rammer findes de sociale bånd, som kan opretholde religion. Fordi den nu kun kan eksistere inden for hjemmets fire vægge, bliver religion usynlig, som Luckmann så smukt udtrykker det. At religion bliver usynlig antyder, at der ikke længere kan skabes enighed om dens plads i det offentlige rum, og at den dermed også bliver privat i forstanden skjult for omverden. I så fald burde individer anse religion som upassende i det offentlige rum, den er jo noget privat.

Man kan afvise ovenstående argument med henvisning til, at religion ikke er blevet usynlig men tværtimod er til stede i det offentlige rum, men som den irske religionssociolog Steve Bruce gør opmærksom på, er det en tilstedeværelse på sekulariseringens vilkår (Bruce 2002, 21). Når religiøse organisationer handler i det offentlige rum, gør de det ikke som religiøse men som verdslige organisationer med de vilkår, dette giver. Som Bruce påpeger, er religiøse argumenter ikke brugbare i en sekulariseret verden. Religiøse aktører ændrer derfor deres argumentation, så den bliver verdslig. Abortmodstand formuleres således som et forsvar for det ufødte individs rettigheder og ikke som en krænkelse af Guds skaberværk. Skilsmisse kritiseres, fordi det er socialt dysfunktionelt, og ikke fordi det er en krænkelse af en institution sanktioneret af Gud. Det antyder, at det religiøse ikke længere anerkendes eller respekteres i det offentlige rum. Her er der kun plads til det verdslige.

Disse punktvise nedslag i sekulariseringsteori peger på, at det fælles rum for samfundets individer er blevet sekulært. Vil religiøse individer og institutioner optræde i det offentlige rum, må de iklæde sig sekulær klædedragt. Alt dette antyder, at selve det religiøse ikke længere er velkomment i det offentlige rum. Dobbelaere formulerer det direkte, mens Luckmann og Bruce antyder det: Sekularisering medfører, at individer får den opfattelse, at religion kun har sin plads i det private.

Ud fra sekulariseringsteori må det forventes, at de holdningsmæssige grænser for den danske religionsmodel er sammenfaldende med grænsen mellem det offentlige og det private rum. Danskerne burde acceptere religion, så længe den relaterer til det private, men være fjendtligt indstillet over for religion, der optræder (religiøst) i det offentlige rum. 


\section{Individualisering}

Hvor sekulariseringsteori forventer en svækkelse af religion, forventer individualiseringsteori en fundamental forandring af det religiøse. At religion og navnlig kirkerne ikke længere har magt over samfundet, fører ikke til nedsat religiøsitet men derimod til en individualisering af religion. Den religiøse magt overføres fra kirkerne til individerne, som nu står med opgaven at skabe og opretholde deres egen religion. Dette medfører ifølge den britiske religionssociolog Grace Davie, at den religiøse tradition opløses, fordi der ikke længere er noget socialt fællesskab til at opretholde den (Davie 2000, 30ff). Men ønsket om en religiøs tradition består, og i stedet for at vende kirkerne ryggen, gør individerne nu kirken til traditionsbevarer; det sted, man går hen for at få den forbindelse til traditionen, som man har mistet, da man overtog ansvaret for sin egen religion. Religiøsiteten er stadig offentlig, men den sker nu på de religiøses vilkår og ikke på kirkens.

Ifølge de britiske religionssociologer Paul Heelas og Linda Woodhead medfører individualisering et skift fra opfattelsen af gud som noget eksternt til noget internt (Woodhead \& Heelas 2005, 5-6). Den eksterne gud er funderet i det normative religiøse fællesskab og i idéen om guds religiøse autoritet. Der er tale om religion bundet til kirke, religiøse autoriteter og en krævende gud. Den interne gud derimod er knyttet til den enkelte og er snarere en form for indre kraft. Det normative aspekt forsvinder således, og den indre gud bliver en støtte til den enkeltes selvudvikling. Dette passer fint med individualiseringen, og magtens forflytning fra organisationen til den enkelte. Den enkelte bliver selv herre over sin egen religion, og med denne magt følger en ændret opfattelse af religion, og af hvad religion og navnlig hvad religiøse institutioner kan og ikke kan tillade sig. Man kan argumentere for, at Heelas og Woodhead ikke er enige med Davie i deres syn på kirkens plads i den individualiserede religion, men begge parter forventer, at individualiseret religiøsitet sker på individers vilkår og ikke på de religiøse autoriteters. Begge forventer et skred fra centraliseret og normativ religion til decentraliseret og ikke-normativ religion.

Ideen om individets religiøse autonomi og deraf følgende reservation over for religiøse autoriteter genfindes også i den danske religionssociolog Ina Rosens studium af danskeres religionsopfattelse. På baggrund af en række fokusgruppeinterviews konstaterer Rosen, at religion i danskeres opfattelse har fire aspekter: tro, religion, praksis og tradition (Rosen 2009, 88ff). Tro er bl.a. trosforestillinger og selve det at tro (og tvivle). Tro er karakteriseret ved at være privat, personligt og noget, den enkelte selv skal finde ud af. Religion derimod er knyttet til religiøse autoriteter og forbindes med rutiniseret og dogmatisk religion. Religion anses for noget, individer påtvinges af f.eks. kirken eller religiøse autoriteter. Praksis er det rituelle udtryk for religion såsom søndagsgudstjeneste, dvs. ritualer som religiøse autoriteter kontrollerer og forsøger at påtvinge individer. Tradition er præcis den religiøse tradition, som kirken er bevarer af, som også Davie ser det. Konkret er der tale om de ritualer, som folk mener, de selv har magt over såsom dåb, bryllup og begravelse. Af en eller anden 
årsag anses netop disse ritualer som værende adskilt fra kirkens og de religiøse autoriteters magt. Ifølge Rosens informanter er det at døbe sit barn en del af en tradition og en kristen kulturarv. Derfor er det acceptabelt at døbe sit barn, men at tage barnet med til en søndagsgudstjeneste eller forsøge at få det til at tro på Gud anses derimod som uacceptabelt. Sidstnævnte er at påtvinge barnet religion. Ligesom religion og praksis er tradition knyttet til kirken, men magtaspektet er tilsyneladende fraværende. Individer deltager i traditionen og dermed visse kirkelige ritualer fordi de ønsker det, og ikke fordi kirken siger, at de skal. Det interessante i denne sammenhæng er, at hvor tro og tradition ses som noget positivt, bliver religion og praksis set på som noget negativt. Når religion har et magtaspekt, når det styres af religiøse autoriteter og forsøges påtvunget individer, så opfattes det som noget negativt og uacceptabelt, men når religion er styret af individet selv, så opfattes det som noget positivt.

Disse tre nedslag i individualiseringsteori antyder alle, at det store skel er mellem selvbestemt og påtvungen religion. Når man selv bestemmer over sin religion og føler, at man selv har magten over den, ses religion som noget positivt og velkomment. Når religion derimod er styret af autoriteter, er den uvelkommen. Man kan derfor argumentere for, at individualiseringsteori forventer, at grænserne for den danske religionsmodel går langs et skel mellem individuel autonomi og ekstern autoritet. Det vigtige er ikke, hvor religion optræder, eksempelvis offentligt eller privat, men derimod med hvilket magtfortegn. Så længe religion afsværger sin autoritet og optræder på individets vilkår, er den velkommen, men så snart den optræder som en autoritet med det formål at påtvinge folk sine synspunkter, er den ikke velkommen hverken i det offentlige eller i det private rum.

\section{Hypoteser}

Med udgangspunkt i teorier om sekularisering må det forventes at:

Hs Danskernes tolerance er markant større over for religion i det private rum end over for religion i det offentlige rum.

Med udgangspunkt i teorier om individualisering må det omvendt forventes at:

$\mathrm{H}_{\mathrm{I}}$ Danskernes tolerance er markant større over for religion som optræder ikkeautoritært end over for religion som optræder autoritært.

Da teorier om sekularisering og teorier om individualisering er formuleret som hinandens modsætninger, kan kun én af hypoteserne bekræftes, ellers må begge afkræftes. 


\section{Data}

Til at teste hypoteserne vil data fra International Social Survey Programme 2008 - Religion III (ISSP 2008) blive anvendt. Denne undersøgelse er velegnet til formålet, da den dels indeholder en række items, som er relevante til at teste hypoteserne, dels er repræsentative, hvorfor resultaterne er generaliserbare for den danske befolkning som helhed.

Der er otte spørgsmål i ISSP 2008, som kan belyse de holdningsmæssige grænser for den danske religionsmodel. Spørgsmålene kan opdeles i fem overordnede emner: social afstand til den religiøse anden, religiøse ekstremisters ytringsfrihed, retten til at bære religiøs påklædning i offentlig funktion, religiøse friskoler samt religion og politik. I Tabel 1 er de otte spørgsmål opstillet (spørgsmålene i deres fulde længde kan ses bagerst i artiklen). Øverst er det spørgsmål, hvor folk er mest positive over for religion i en given sammenhæng. Nederst er det spørgsmål, hvor folk er mindst positive over for religion i en given sammenhæng. Med andre ord: øverst er de områder hvor danskerne i højst grad mener, at religion har en plads inden for rammerne af den danske religionsmodel. Nederst er de områder, hvor danskerne i mindst grad mener, at religion hører til. Et sted mellem disse to yderpunkter kan man påstå, at den holdningsmæssige grænse for den danske religionsmodel går.

\begin{tabular}{ll}
\hline Religiøs anden gifte sig med din slægtning & 79 \\
Religiøs anden stille op for dit parti & 73
\end{tabular}

\begin{tabular}{ll}
\hline Religiøse ekstremister udgive bøger & 59 \\
Religiøse ekstremister holde offentlige møder & 45
\end{tabular}

Religiøs påklædning i offentlig funktion $\quad 38$

Religiøse have egne skoler $\quad 31$

$\begin{array}{ll}\text { Præster påvirke politik } & 9 \\ \text { Præster påvirke afstemning } & 7\end{array}$

Tabel 1: Danskernes holdning til religion (i pct.)

Kilde: ISSP 2008 - Religion III

Tallene angiver andelen som svarede inden for de to mest positive kategorier, hvis der var mere end to svarkategorier i spørgsmålet 
Folk har forskellige religioner og forskellige religiøse holdninger. Ville du acceptere, at en person med en anden religion eller med meget anderledes religiøse holdninger end dine...

...giftede sig med en af dine slægtninge?

...opstillede som kandidat for det politiske parti du sympatiserer med?

(Helt sikkert acceptere, Sandsynligvis acceptere, Sandsynligvis ikke acceptere, Helt sikkert ikke acceptere)

Nogle mennesker har holdninger, som flertallet af befolkningen anser for at være yderligtgående. Prøv at tænk på religiøse ekstremister, dvs. mennesker som mener at netop deres religion er den eneste sande og at alle andre religioner er deres fjender. Mener $\mathrm{du}$, at sådanne mennesker skal have lov til at:

Udgive bøger for at give udtryk for deres holdninger?

Afholde offentlige møder for at give udtryk for deres holdninger?

(Helt sikkert, Sandsynligvis, Sandsynligvis ikke, Helt sikkert ikke)

Bør det være tilladt for mennesker, som i deres arbejde betjener offentligheden, at klæde sig på en måde, der viser deres tro, fx ved at gå med slør, turban eller kors?

(Ja, Nej)

Nogle skoler er for børn med en bestemt religiøs baggrund. Hvilke af følgende udsagn kommer tættest på din egen holdning til disse skoler?

(Ingen religiøs gruppe bør have sin egen skole, Nogen religiøse grupper bør have deres egne skoler, men andre bør ikke, Alle religiøse grupper bør have mulighed for at have deres egne skoler)

Hvor enig eller uenig er du i hvert af følgende udsagn?

Præster og andre religiøse ledere bør ikke forsøge at påvirke politiske beslutninger.

Præster og andre religiøse ledere bør ikke forsøge at påvirke, hvordan folk stemmer ved valgene.

(Helt enig, Delvis enig, Hverken enig eller uenig, Delvis uenig, Helt uenig) 


\section{Sekulariseringstesen}

Der er to måder at teste om sekulariseringsteori kan forklare danskernes holdning til religions rette plads. Den ene måde er at sammenligne, om der er forskel på holdningen til religion i det offentlige rum og religion i det private rum. Hypotese $\mathrm{H}_{\mathrm{s}}$ forventer, at danskerne vil være afvisende over for religion, der optræder i det offentlige rum, mens de vil være mere tolerante over for religion i det private rum. Den anden måde at teste sekulariseringstesen i forhold til den danske religionsmodel er at vurdere, om danskernes holdning til religion i det offentlige rum er nogenlunde konsistent. Hvis hypotese Hs er korrekt, burde størstedelen af danskerne være nogenlunde lige afvisende over for religion i det offentlige rum uanset de specifikke omstændigheder.

De to spørgsmål om social afstand til den religiøse anden giver mulighed for at teste sekulariseringstesen ved at undersøge danskernes holdning til religion i det offentlige rum. De spørger, om man ville acceptere, at en person med en anden religion giftede sig med ens slægtning eller stillede op for ens foretrukne politiske parti (henholdsvis øverste og næstøverste spørgsmål i Tabel 1). Man kan argumentere for, at den første del af spørgsmålet berører det private rum, mens den anden del af spørgsmålet berører det offentlige rum. Ud fra sekulariseringstesen må det forventes, at der er markant højere tilslutning til første del af spørgsmålet, end der er til anden del. Det kan ikke påstås at være tilfældet. Cirka 79 pct. stiller sig positive over for, at en person med et andet religiøst tilhørsforhold gifter sig med ens slægtning, mens 73 pct. stiller sig positivt over for, at den religiøse anden stiller op for ens foretrukne politiske parti.

De to spørgsmål om religiøse ekstremisters ytringsfrihed spørger, om man mener, at religiøse ekstremister skal kunne holde offentlige møder for at give udtryk for deres holdninger eller kunne udgive bøger af samme årsag (henholdsvis fjerde og tredje spørgsmål fra oven i Tabel 1). Det er indlysende, at spørgsmålet om offentlige møder berører religion i det offentlige rum. Spørgsmålet om bogudgivelser kan både tolkes som religion i det offentlige og i det private rum. Fordi bogudgivelser er tilgængelige for alle, kan man argumentere for at spørgsmålet berører religion i det offentlige rum, men da bøger som oftest læses inden for hjemmets fire vægge, kan man også argumentere for at spørgsmålet berører religion i det private rum. Tolker man bogudgivelser som hørende til det private rum, kan der argumenteres for, at der er belæg for hypotese $\mathrm{H}_{\mathrm{s}}$, idet danskerne er mere positive over for religion i det private rum end over for religion i det offentlige rum. 59 pct. stiller sig positive overfor, at ekstremister udgiver bøger, mens 45 pct. stiller sig positive overfor, at religiøse ekstremister holder offentlige møder. Tolker man omvendt bogudgivelser som udtryk for religion i det offentlige rum, er forskellen i accept for stor til, at den udtrykker en sammenhængende holdning til religion i det offentlige rum blandt danskerne.

Den anden fremgangsmåde beskrevet ovenfor kræver, at alle spørgsmål som måler holdningen til religion i det offentlige rum sammenlignes for at teste, om de har 
tilnærmelsesvis ensartede svarmønstre. Andelen som stiller sig positive overfor, at den religiøse anden stiller op for deres foretrukne parti, og andelen som stiller sig positive overfor, at religiøse ekstremister afholder offentlige møder, er sammenlignelige, henholdsvis 53 pct. og 45 pct. Ser man derimod på holdningen til at blande religion og politik, er billedet meget anderledes. 9 pct. stiller sig positive overfor, at præster og andre religiøse ledere bør påvirke politiske beslutninger, og 7 pct. stiller sig positive overfor, at præster og andre religiøse ledere bør påvirke, hvordan folk stemmer ved valgene (henholdsvis syvende og ottende spørgsmål fra oven i Tabel 1). Her er danskerne altså markant mere negativt indstillede over for religion i det offentlige rum, end hvad tilfældet var i forbindelse med den religiøse anden og religiøse ekstremister. Til sammenligning stiller 38 pct. sig positive over for, at personer, som betjener offentligheden i deres arbejde, viser deres tro f.eks. ved at gå med slør, mens 31 pct. stiller sig positive overfor, at (i hvert fald visse) religiøse grupper bør have deres egne skoler (henholdsvis femte og sjette spørgsmål fra oven i Tabel 1). På trods af at alle seks ovennævnte spørgsmål måler holdningen til religion i det offentlige rum, svinger danskernes accept fra 73 pct., når det gælder den religiøse andens ret til at stille op for respondentens foretrukne parti til 7 pct., som er positive overfor, at præster og andre religiøse ledere bør påvirke, hvordan folk stemmer. Selv hvis man vælger at se det offentlige og det private rum som punkter på et kontinuum snarere end som en dikotomi, er forskellen på 66 procentpoint simpelthen for stor til, at det med rette kan påstås, at danskerne holdning til religion i det offentlige rum er bare nogenlunde konsistent.

Anvender man første fremgangsmåde til at teste sekulariseringstesen, kan tesen kun bekræftes, hvis man anvender en diskutabel tolkning af det at udgive bøger som tilhørende det private rum. Anvender man den anden fremgangsmåde, er forskellene i accept af religion i det offentlige rum så forskellige på tværs af de konkrete tilfælde, at man ikke kan påstå, at danskerne har en konsistent holdning til religion i det offentlige rum. Ud fra de empiriske resultater må hypotese $\mathrm{H}_{\mathrm{s}}$ afvises, idet danskernes tolerance ikke kan påstås at være markant større over for religion i det private rum end over for religion i det offentlige rum.

\section{Individualiseringstesen}

Ligesom med sekulariseringstesen er der to måder at teste individualiseringstesen på. En er at sammenligne holdningen til religion i situationer, hvor der optræder religiøs autoritetsudøvelse og situationer, hvor religion alene er et udtryk for individets egen selvstændige religiøsitet. Ud fra hypotese $H_{\text {I }}$ må det forventes, at danskerne er langt mere positive over for religiøs selvudfoldelse end over for eksempler på religiøs autoritetsudøvelse. En anden måde at teste individualiseringstesen er at sammenligne holdningerne til henholdsvis situationer med religiøs autoritetsudøvelse og situationer med religiøs selvudfoldelse, for at afgøre om danskernes holdninger 
til religion i disse to situationer er konsistente. Individualiseringstesen forventer, at danskerne er positive over for religiøs selvudfoldelse uanset de specifikke omstændigheder, og negativt indstillede over for religiøs autoritetsudøvelse igen uanset de specifikke omstændigheder.

De otte spørgsmål fra ISSP 2008 bliver delt imellem dem, hvor der optræder religiøs autoritetsudøvelse og dem, hvor der optræder religiøs selvudfoldelse. For at kunne skelne vil fokus være på, om spørgsmålene berører religiøse menneskers mulighed for at påvirke andre, eller om de berører menneskers mulighed for religiøs selvudfoldelse. Ud fra individualiseringsteori må det forventes, at danskerne vil være positivt indstillet over for personlig religiøs autonomi og frihed, mens de vil være negativt indstillet over for at lade andre mennesker eller organisationer bruge deres religiøse frihed til at begrænse andres religiøse autonomi.

De to spørgsmål, der omhandler hvorvidt præster må påvirke, hvordan folk stemmer og påvirke politiske beslutninger, kan begge tolkes derhen, at de berører præster og andre religiøse lederes mulighed for at bruge deres religiøse frihed til at begrænse andre individers religiøse autonomi. Spørgsmålene om religiøse skoler og retten til at bære religiøse symboler på arbejdet er en mellemting. På den ene side er begge spørgsmål formuleret på en sådan måde, at den religiøses ret og dermed selvudfoldelse er i centrum. På den anden side kan man argumentere for, at de begge berører den religiøses mulighed for at påvirke andre religiøst. Skoler i Danmark kan siges at have en opdragende funktion, hvorfor en religiøs skole kan tolkes som et forsøg på at begrænse børns religiøse autonomi. Eftersom at visse politikere sætter lighedstegn mellem muslimske tørklæder og hagekors i pressen (f.eks. Pia Kjærsgaard i TV-Avisen, DR1, 29-4-2007) kan man argumentere for, at nogle danskerne ser det at bære slør som et forsøg på at påvirke eller ligefrem påtvinge andre deres religion. Begge spørgsmål kan således tolkes som udtryk for religiøs selvudfoldelse og som udtryk for den religiøses mulighed for at påvirke andre (hvor sekundært et fokus det end måtte være i spørgsmålene). De resterende fire spørgsmål er formuleret på en sådan måde, at de primært må tolkes derhen, at de berører andre individers mulighed for at udfolde deres religiøse autonomi.

Sammenligner man danskernes holdning til religion i situationer med religiøs autoritetsudøvelse og religion i situationer med religiøs selvudfoldelse, stemmer det overens med individualiseringstesen. De to spørgsmål som her tolkes som udtryk for religiøs autoritetsudøvelse (syvende og ottende spørgsmål fra oven i Tabel 1) er de spørgsmål, som færrest giver et positivt svar. Omvendt får de spørgsmål, som her tolkes som udtryk for den enkeltes religiøse autonomi (de fire øverste spørgsmål i Tabel 1), flest positive svar. De to spørgsmål, som kan tolkes både som udtryk for religiøs autoritetsudøvelse og som udtryk for individets religiøse autonomi (femte og sjette spørgsmål fra oven i Tabel 1), får et antal positive svar, som ligger midt imellem. 45 pct. af danskerne stiller sig positive over for, at religiøse ekstremister skal kunne holde offentlige møder, men kun cirka 9 pct. stiller sig positive overfor, at 
præster og andre religiøse ledere må forsøge at påvirke politiske beslutninger. Forskellen i positive tilkendegivelser på spørgsmålene er 36 procentpoint. Det er så stor en forskel, at det må konkluderes, at danskernes tolerance er markant større over for religion i situationer med religiøs selvudfoldelse end over for religion i situationer med religiøs autoritetsudøvelse. Det forstærker kun konklusionen, at afstanden mellem spørgsmålet om religiøs autoritetsudøvelse, som danskerne var mest positive overfor og spørgsmålet om religiøs autonomi, som danskerne var mindst positive overfor er 36 procentpoint (afstanden mellem det spørgsmål som flest svarede positivt på og det som færrest svarede positivt på er hele 72 procentpoint).

Bemærk også hvem aktørerne er i spørgsmålene om religiøse ekstremisters ret til at holde offentlige møder, og om hvorvidt præster og andre religiøse ledere bør påvirke politiske beslutninger. I det første spørgsmål er aktørerne religiøse ekstremister. For de fleste danskere vil det formentlig blive tolket negativt som en henvisning til muslimske maksimalister som f.eks. Hizb ut-Tahrir. I det andet spørgsmål er aktørerne præster og andre religiøse ledere. Ordet præst vil formentlig af de fleste blive tolket som en henvisning til præster i folkekirken, som jo er den slags præster, som er mest synlige i danskernes bevidsthed. Analyser af den europæiske værdiundersøgelse har vist, at danskerne er blevet mere åbne over for en offentlig rolle for folkekirken og dermed også over for dens præster, må man formode (Andersen \& Lüchau 2011). Det betyder også, at det næppe er den religiøse aktør, som er det centrale i de to spørgsmål, men derimod hvad de to religiøse aktører foretager sig. Selv ellers vellidte præster afvises, hvis de forsøger at udøve religiøs autoritet, mens selv religiøse ekstremister kan accepteres, når bare de ikke forsøger at påtvinge andre deres religiøse opfattelser.

Spørgsmålene om hvorvidt religiøse grupper bør have deres egne skoler, og om folk må bære religiøse symboler, når de betjener offentligheden i deres arbejde, kunne som nævnt tolkes både som udtryk for individets religiøse autonomi og som udtryk for religiøs autoritetsudøvelse. Disse spørgsmål havde som nævnt en accept, som lå midt imellem de to andre grupper af spørgsmål, idet henholdsvis 31 pct. af danskerne accepterede, at visse religiøse grupper havde deres egne skoler og 38 pct. accepterede, at folk, der betjener offentligheden i deres arbejde, kunne bære religiøse symboler. Når det er sagt, er det værd at bemærke, at danskerne er langt mere positive over for, at religiøse bør have deres egne skoler end overfor, at præster må forsøge at påvirke politiske beslutninger. 31 pct. stiller sig positive over for det førstnævnte, mens 9 pct. stiller sig positive over for det sidstnævnte. Det antyder, at danskerne finder, at det primære aspekt i spørgsmålene om religiøses ret til at bære f.eks. slør på arbejdet og drive deres egne skoler, er religiøs autonomi. At spørgsmålene kan tolkes tvetydigt, forstærkes af, at over 12 pct. af de adspurgte ikke kunne besvare spørgsmålene. Danskerne er med andre ord næppe enige om, hvilket aspekt af de to problemstillinger, som vejer tungest. 
Holdningen til religiøs autoritetsudøvelse må siges at være konsistent. 7 pct. mener, at præster må forsøge at påvirke, hvordan folk stemmer til valgene, og 9 pct. mener at de må forsøge at påvirke politiske beslutninger. Forskellen i accepten er så lille, at den reelt set er ikke-eksisterende. Ser man på spørgsmålene om religiøs selvudfoldelse, er forskellene større. 79 pct. stiller sig positive overfor, at en person med anden religiøs baggrund gifter sig med en af den adspurgtes slægtninge, mens 45 pct. stiller sig positive overfor, at religiøse ekstremister må afholde offentlige møder. Forskellen er 34 procentpoint, og spredningen dermed større. På den anden side er denne forskel markant mindre end den forskel, der var på accepten af religion i det offentlige rum, hvor forskellen var 66 procentpoint. I den forstand kan man argumentere for, at holdningen til religiøs autonomi er mere konsistent end holdningen til religion i det offentlige rum, idet spredningen i accept er klart mindre her.

Det må konkluderes, at danskerne er langt mere positive over for religiøs selvudfoldelse end over for religiøs autoritetsudøvelse. Det må også konkluderes, at danskernes holdning til religiøs autoritetsudøvelse er konsistent, og der kan argumenteres, for at danskernes holdning til religiøs selvudfoldelse ligeledes er konsistent omend ikke i lige så ekstrem grad. Hermed er hypotese $\mathrm{H}_{\mathrm{I}}$ bekræftet, idet den empiriske analyse har vist, at danskernes tolerance er markant større over for religion i situationer med religiøs selvudfoldelse end over for religion i situationer med religiøs autoritetsudøvelse.

Resultatet af den empiriske analyse er konsistent med den teoretiske forventning, idet sekulariseringstesen måtte afvises, mens individualiseringstesen blev bekræftet. Som nævnt betyder de to tesers modsætningsforhold, at kun én af dem skulle kunne bekræftes. Havde de begge været bekræftet, ville de begge skulle være afvist af teoretiske årsager. Den samlede konklusion på baggrund af Tabel 1 bliver således, at de holdningsmæssige grænser for den danske religionsmodel ikke afgøres af, hvor religion optræder, men i hoilken rolle.

\section{Den danske religionsmodels holdningsmæssige grænser i det danske værdimæssige landskab}

Spørgsmålet er så, om danskere er enige om, hvor de holdningsmæssige grænser for den danske religionsmodel går, eller om spørgsmålet deler dem på tværs af eksisterende grupper. Er de holdningsmæssige grænser for den danske religionsmodel for eksempel en del af en politisk skillelinje, ligesom holdningen til indvandrere er det (se Thomsen 2006, 149ff)? Hvis det er tilfældet, kunne det kaste lys på forholdet mellem de politiske og holdningsmæssige grænser for den danske religionsmodel.

Hvis de holdningsmæssige grænser er en del af en politisk skillelinje, skal de flugte eksisterende skillelinjer, som ofte defineres af politisk orientering, uddannelse, alder og urbanisering. Da der er tale om grænser for religion, er det oplagt også at tage religiøsitet med i analysen. Konkret er der lavet en række multivariate analyser 
af de otte spørgsmål i Tabel 1. Alle er blevet anvendt som afhængige variable i en OLS multiple regression med selvplacering på en politisk venstre/højre skala, højeste færdiggjorte uddannelse, alder, antal indbyggere i hjemby samt kirkegang som uafhængige variable. Spørgsmålene om personer, som betjener offentligheden i deres arbejde må vise deres tro, og om religiøse bør have deres egne skoler, er testet ved hjælp af logistisk regression men med samme uafhængige variable. Multivariate analyser kan vise, hvad som er styrende for danskernes accept af religion i bestemte situationer, når man tager effekten af alle uafhængige variable i betragtning på samme tid. Analysen prioriterer så at sige mellem de mulige forklaringer, så man kan afgøre, hvad som er den vigtigste.

De multivariate analyser viser to ting. For det første at danskernes holdninger til religions rette plads fordeler sig langs eksisterende værdimæssige kløfter. For det andet at disse kløfter er forskellige alt efter hvilke specifikke spørgsmål, der er tale om.

De tre spørgsmål, som danskerne stiller sig mindst positive overfor, er alle styret af den samme bagvedliggende faktor nemlig graden af religiøsitet, forstået som hvor ofte man går i kirke. Jo oftere folk går i kirke, jo mere åbne er de overfor, at præster kan påvirke, hvordan folk stemmer, kan påvirke politiske beslutninger og overfor, at religiøse bør have mulighed for at danne deres egne skoler. Åbenhed over for religiøs autoritetsudøvelse findes primært blandt individer, som selv er mere religiøst aktive end gennemsnittet. Man kan man sige, at disse mennesker er en del af den traditionelle eller kollektive måde at være religiøs på, som individualiseringen jo netop er en bevægelse væk fra.

Accept af at personer med en anden religion gifter sig med ens slægtning eller stiller op for ens foretrukne parti og accept af religiøse ekstremisters ytringsfrihed er styret af de samme to faktorer nemlig uddannelse og politisk orientering. Jo længere uddannelse man har, jo mere åben er man over for religiøs selvudfoldelse, og jo mere højreorienteret man er, jo mindre åben er man over for religiøs selvudfoldelse.

Danskerne er generelt enige, når det gælder det, som er udenfor de holdningsmæssige grænser for religionsmodellen, dvs. udøvelsen af religiøs autoritet. Her er politiske holdninger, alder, uddannelse og urbanisering ikke en faktor. Kun de traditionelt religiøse skiller sig ud. Holdningen til religiøs selvudfoldelse derimod lægger sig langs eksisterende værdimæssige kløfter, der netop skiller i forhold til politisk orientering og uddannelse. Eller sagt på en anden måde: Alle de situationer, hvor danskerne accepterer tilstedeværelsen af religion, er en almindelig del af det værdimæssige landskab i Danmark. De egenskaber ved et individ, som forklarer dets holdninger til f.eks. indvandring og skattepolitik, er de samme, som styrer deres holdning til religiøs selvudfoldelse. De venstreorienterede og de højtuddannede er mere tolerante end de højreorienterede og de lavere uddannede, hvad enten det gælder øget indvandring, højere skatter eller religiøs selvudfoldelse. Kun religiøs autoritetsudøvelse, som jo netop er uden for religionsmodellens grænser, er usæd- 
vanligt, derved at religiøsitet er en faktor. Alle andre på tværs af uddannelse og politiske uenigheder er enige om, at religion, som optræder autoritært, er uacceptabelt.

Spørgsmålet om, hvorvidt man må vise sin religiøse overbevisning gennem sin påklædning, når man betjener offentligheden i sit arbejde, er usædvanligt derved, at det deler danskerne langs flere værdimæssige skillelinjer. Både politisk orientering, alder, kirkegang og uddannelse viser sig at være styrende for, hvordan danskerne svarer på spørgsmålet. Det betyder, at holdningen til dette spørgsmål både skiller danskerne langs eksisterende værdimæssige kløfter og langs en religiøs skillelinje. Danskerne kan ikke afgøre med sig selv, om det er acceptabelt eller uacceptabelt, og derfor er både religiøsitet og uddannelse og politisk orientering bagvedliggende faktorer. Betragter man de otte spørgsmål som en form for skala, kan man argumentere for, at danskerne opfattelse af, hvor religions rette plads er i samfundet skiller ved, om personer skal have lov at vise deres tro over for offentligheden i deres arbejde.

\section{Konklusion}

Målene med denne artikel var trefold: at vise hvor de holdningsmæssige grænser for den danske religionsmodel går, forklare hvorfor de går, hvor de går, og undersøge om de lægger sig langs eksisterende værdimæssige kløfter i Danmark.

Analysen af ISSP 2008 viste, at de holdningsmæssige grænser for den danske religionsmodel gik langs et skel mellem religiøs selvudfoldelse og religiøs autoritetsudøvelse. Som danskerne ser det står det enhver frit at være religiøs på sin egen måde. Selv religiøse ekstremister har denne ret. At forsøge at udøve religiøs autoritet over andre er derimod uacceptabelt, selv når autoriteten udøves af folkekirkens præster.

At de holdningsmæssige grænser for den danske religionsmodel går mellem religiøs selvudfoldelse og religiøs autoritetsudøvelse, passer fint med individualiseringstesen. Hypotese $\mathrm{H}_{\mathrm{I}}$ bekræftes, idet danskernes tolerance er markant større over for religion i situationer, hvor religion alene er et udtryk for individets egen selvstændige religiøsitet end situationer, hvor der optræder religiøs autoritetsudøvelse. Omvendt passer de holdningsmæssige grænser dårligt med sekulariseringstesen og hypotese $\mathrm{H}_{s}$ må afvises, da danskernes tolerance ikke kan siges at være markant større over for religion i det private rum end over for religion i det offentlige rum. Danskerne har det fint med, at deres slægtning gifter sig med en person med en anderledes religion, og de har det også fint med, at deres foretrukne politiske parti opstiller denne religiøse anden som kandidat. Det vigtige er ikke, hvor religion optræder, men med hvilken intention, det sker.

At grænserne for den danske religionsmodel kan forklares ud fra individualiseringsteori antyder, at individualisering ikke alene har ændret måden danskerne er 
religiøse på (se Andersen \& Lüchau 2011) men også deres holdning til religion i det hele taget. Det antyder desuden et vigtigt perspektiv til at forstå nuværende konflikter om religion i det danske samfund. Man kunne eksempelvis argumentere for, at den megen modstand mod islam i den danske offentlighed netop skyldes, at islam fremstilles som en religion, der ønsker at bedrive religiøs autoritetsudøvelse f.eks. ved at tvinge kvinder til at gå med slør eller indføre sharia lovgivning.

De holdningsmæssige grænser for den danske religionsmodel lægger sig langs eksisterende værdimæssige kløfter i Danmark. Så længe der er tale om det, som er inden for religionsmodellens accepterede grænser, dvs. religiøs selvudfoldelse, er uddannelse og politisk orientering afgørende for folks holdninger. Er der derimod tale om det, som er uden for de accepterede grænser, religiøs autoritetsudøvelse, er religiøsitet den afgørende faktor. Der syntes således at være et skel mellem de, som har en traditionel, kollektiv og normativ religiøsitet, og resten af danskerne, når det gælder religiøs autoritetsudøvelse. Danskerne er på tværs af eksisterende værdimæssige kløfter enige om at afvise religiøs autoritetsudøvelse. På dette område er religiøsitet den eneste skillelinje. Dette antyder, at normativ religiøsitet i sig selv er et randfænomen, som afvises på tværs af eksisterende værdimæssige kløfter blandt danskerne. Det, som er inden for de holdningsmæssige grænser for den danske religionsmodel, er derimod en integreret del af det danske værdimæssige landskab. En del af det at være dansk.

\section{LITTERATUR}

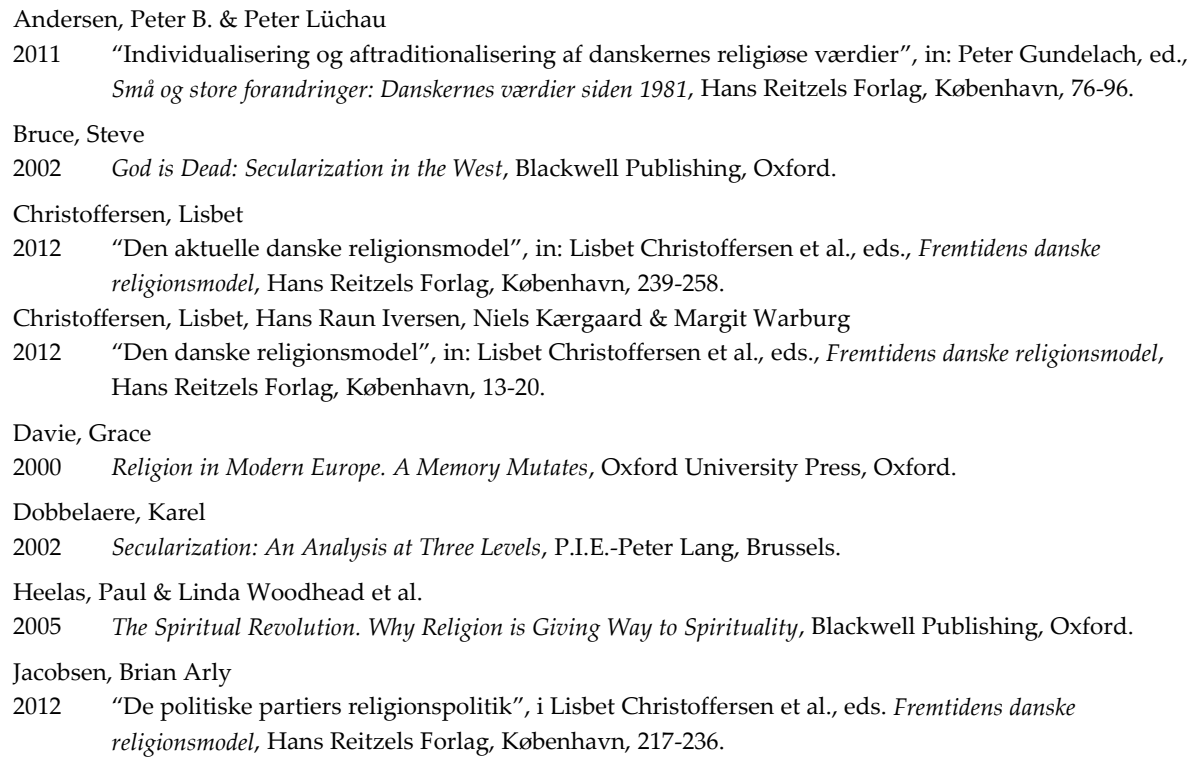




\section{Luckmann, Thomas}

1967 The Invisible Religion: The Problem of Religion in Modern Society, The MacMillan Company, New York.

Lüchau, Peter \& Peter B. Andersen

2012 "Socio-Economic Factors Behind Disaffiliation from the Danish National Church", Nordic Journal of Religion and Society 25 (1), 27-45.

Rosen, Ina

2009 I'm a believer - but I'll be damned if I'm religious. Belief and religion in the Greater Copenhagen Area - A focus group study [Lund Studies in Sociology of Religion, Vol. 8], Lunds Universitet, Lund.

Thomsen, Jens Peter Frølund

2006 Konflikten om de nye danskere: Om danskernes holdninger til etniske minoriteters kultur og rettigheder, Akademisk Forlag, København.

Peter Lüchau, post.doc., ph.d. Sociologisk Institut, Københavns Universitet 